\title{
Tumor derived stress triggers C/EBP $\beta$ homologous protein (Chop) expression in myeloid derived suppressor cells (MDSC) and mediates immunosuppressive activity
}

\author{
Paul Thevenot ${ }^{*}$, Rosa Sierra, Patrick Raber, Paulo Rodriguez \\ From Society for Immunotherapy of Cancer 29th Annual Meeting \\ National Harbor, MD, USA. 6-9 November 2014
}

Suppression of anti-tumor T cell responses by MDSC remains a significant barrier in cancer immunotherapy. Although several pathways have been characterized as critical for MDSC-induced suppression, there are currently no therapies to globally and specifically inhibit MDSC function. We postulate that identifying and inhibiting the central mediators of MDSC-regulatory activity will overcome $\mathrm{T}$ cell suppression and increase the efficacy of T cell-based immunotherapy in cancer. We aimed to determine the role of the common stress sensor C/EBP-homologous-stress-related protein (Chop), a downstream product of integrated stress responses, as a master regulator of MDSC-suppressive activity. Our results show that Chop is preferentially expressed in malignant cells and MDSC in s.c. mouse tumors. Selective expression of Chop was also detected in tumor-infiltrating MDSC from colon carcinoma patients. Interestingly, injection of tumor cells having functional Chop into systemic Chop -/- mice or Chop null bone marrow chimeric mice resulted in a significant antitumor effect mediated by $\mathrm{CD} 8^{+} \mathrm{T}$ cells, suggesting the importance of MDSC-Chop in tumor-induced tolerance. In fact, deletion of Chop in MDSC increased the efficacy of $\mathrm{T}$ cell-based immunotherapy. MDSC isolated from tumor-bearing Chop null mice had decreased ability to block $\mathrm{T}$ cell responses; impaired expression of major MDSC-inhibitory pathways; and a surprising ability to prime $\mathrm{T}$ cell proliferation and induce anti-tumor effects. Accordingly, depletion of $\mathrm{Gr}-1^{+}$MDSC restored tumor growth in Chop -/- mice, while it prevented tumor growth in wild type mice, confirming functional differences in MDSC from wild type and Chop -/- mice. To therapeutically block Chop in tumors, we used a specific liposomal-encapsulated siRNA, which successfully blocked Chop expression and induced anti-tumor effects. We next examined the effects of Chop on C/EBP $\beta$ and STAT-3, both master regulators of MDSC function. MDSC from Chop -/- mice had elevated expression of C/EBP $\beta$ inhibitory isoform LIP, low C/EBP $\beta$ binding to IL-6-promoter, decreased IL- 6 production, and impaired expression of IL-6 target phospho-STAT-3. Also, Chop -/- MDSC expressed higher levels of miR-142-3p, a mi-RNA that promotes C/EBP $\beta$ LIP over LAP and LAP*. Ectopic expression of IL- 6 in tumors restored tumor growth, MDSC suppression, and C/EBP $\beta$ and phospho-STAT-3 levels in Chop -/- mice, suggesting the role of this pathway in the effects induced by Chop deletion. Collectively, this data suggests the role of Chop as a master regulator of the immune inhibitory activity of MDSC and justify the potential targeting of Chop as a way to restore protective immunity in cancer.

\section{Consent}

Written informed consent was obtained from the patient for publication of this abstract and any accompanying images. A copy of the written consent is available for review by the Editor of this journal.

Published: 6 November 2014 
doi:10.1186/2051-1426-2-S3-016

Cite this article as: Thevenot et al:: Tumor derived stress triggers C/EBP $\beta$ homologous protein (Chop) expression in myeloid derived suppressor cells (MDSC) and mediates immunosuppressive activity. Journal for ImmunoTherapy of Cancer 2014 2(Suppl 3):016.

Submit your next manuscript to BioMed Central and take full advantage of:

- Convenient online submission

- Thorough peer review

- No space constraints or color figure charges

- Immediate publication on acceptance

- Inclusion in PubMed, CAS, Scopus and Google Scholar

- Research which is freely available for redistribution

Submit your manuscript at www.biomedcentral.com/submit

Ciomed Central 